\title{
Handling Customers' Objection as an Entrepreneurial Function: A Study of Sachet Water Industry in Cross River State, Nigeria
}

\author{
Felix John Eze ${ }^{1} \&$ Ireneus Chukwudi Nwaizugbo ${ }^{2}$ \\ ${ }^{1}$ Department of Marketing, University of Calabar, Cross River State, Nigeria \\ ${ }^{2}$ Department Of Marketing, Nnamdi Azikiwe University, Awka Anambra State, Nigeria \\ Correspondence: Department of Marketing, University of Calabar, Cross River State, Nigeria. E-mail: \\ ezefelixjohn@yahoo.com
}

Received: June 25, 2012 Accepted: August 7, 2012 Online Published: September 10, 2012

doi:10.5539/ijms.v4n5p66 URL: http://dx.doi.org/10.5539/ijms.v4n5p66

\begin{abstract}
The study evaluated the association between consumers' objection and entrepreneurial function among selected entrepreneurs and customers of sachet water in Calabar, Cross River State, Nigeria. Specifically, the study hinges on determining the relationship between consumer's objection and long term customer loyalty, the extent to which price objection affect entrepreneur's profitability and whether entrepreneurs are responsive to price objection. The survey research design was used while Pearson Correlation Coefficient was used for the hypothetical tests. The results showed that: there is a significant relationship between consumer's objection and entrepreneurial function; entrepreneurs were not responsive to consumers' price objection, and there was a relationship between consumer's objection and customer loyalty. It was therefore recommended that objections be expected and noted for future references and be responded to, as it encourages the understanding of the customers' request and ensure customer satisfaction if adequately handled. Reckoning that, success hinges on efficient managerial ability.
\end{abstract}

Keywords: entrepreneurial function, customer's objections, customer loyalty, customer focus

\section{Introduction}

An entrepreneur is the person that assumes the risk of assembling resources in such a form that it produces solution to human needs for a reward called profit. The entrepreneur acts in different ways to bring to light something unique which represent value, benefit, and satisfaction in the eye of the buyer or customer through the use of effective and efficient marketing function. To sustain and grow the business, entrepreneurs have learnt to situate the business on the platform of marketing orientation which ensures that meeting the needs of the customers satisfactorily remains the drive of the organization. Marketing orientation is a business philosophy which believes that the sole purpose of any business is to identify the needs of the market, then galvanizing the organizations resources to competitively packages and delivers solutions to that needs satisfactorily at profit to the organization. In practice, the marketing orientation stands on the three fundamental principles of consumer satisfaction, profitable sales volume and effective implementation of marketing efforts.

The philosophy has proved so beneficial that most organizations have adopted the philosophy of marketing orientation because it has been shown that the only thing that sustains any business organization in the market is the continual and updated knowledge of consumer/customer needs and meeting such needs more satisfactorily and profitably to the market. One of marketing methods for delivering need satisfying products to the market is through selling. Selling according to Kalu and Anyaogu (2007) refers to the personal communication of information to persuade a prospective customer to buy something - good service, idea or something else - that satisfies that individual's needs, and the process flows from prospecting through to closing sales. It affords the marketer the opportunity for personal contact with the potential client or customer for the purpose of presenting the product, discussing price and other conditions, and eventually consummating the exchange relationship. It also affords the customer the opportunity to ask questions, make clarifications and in fact raise objections on any aspect of the details of presentation.

Objection is more or less associated with customer's resistance at the point of initiating transaction or early stages of business relationship; whereas complaint is associated product use experience of an existing customer. 
Objection highlights the issues which are important to the buyer. According to Jobber and Lancaster, (2006) objections are any concern or questions raised by the buyer. Some objections are an expression of confusion, doubt or disagreement with the statement or information presented by the entrepreneur salesperson. Many objections are simply expressions of interest by the buyer. What the buyer is asking for is further information because he/she is interested in what the entrepreneur salesperson is saying. Objections can be classified into:

(a) Valid objections - such as justifying cost or need, fear of making wrong choice, search for reassurance, which are the real worries.

(b) Invalid objection - these include trifling excuses, blind prejudices, not wanting to surrender without a fight.

(c) Hidden objections which need to be brought to light by careful questions.

\section{Statement of Problem}

Despite the popular claim that most entrepreneurs practice consumer orientation, opinions and general marketing report show a high incidence of customer objections and complaints. Customer objection and complain is not a phenomenon that is limited to the domestic market, but one that has raved havoc even in international communities. It was this situation that gave rise to consumerism, a movement by the consumers in protest of the fraudulent activities of marketing organizations and the signing of the Charter of Consumer Rights. Consumer objection and complaints are common in the areas of poor quality and sub-standard products, fraudulent measures and delivery conditions, misleading information and false advert messages and unjust prices.

In Nigeria, cases' relating to price objection and complaints is reasonably high compared to other objections and complaints raised by customers. This is not unexpected as the customer usually compares the perceived value of the product bought against the price paid for it such that any instance of price being greater than perceived value gives rise to objection, complain, resentment, boycott, protest or such expression of dissatisfaction. It has been observed that most consumers of sachets water in Calabar metropolis are objecting to the price of sachet water on the ground that potable water is available and accessible in sufficient quantity; and that sachet water was cheaper in some neighboring states which are not as much endowed with potable water. Drawing emphasis in the words of David (2007), the customers are saying "you are too expensive as compared to your competitors" and that "we like your product but we can't afford it". Unfortunately, the entrepreneurs have not responded to the objections in a satisfactory manner, thereby raising a doubt whether the entrepreneurs really understand that addressing objections and complaints is a challenge they take with all sense of responsibility in the interest of their business. The purpose of this paper therefore is to evaluate the responsiveness of entrepreneurs to customer objection as an entrepreneurial function that provides a platform for developing customer patronage and loyalty in their products Calabar, Cross Rivers State. The specific objectives of the study are:

- To determine the relationship between consumer's objection and long term customer loyalty?

- To determine the extent price objection affect entrepreneur profitability in Calabar metropolis?

- To find out whether entrepreneurs in the sachet water industry in Calabar, Cross River State (CRS) are responsive to price objection?

This paper examines the impact of customers objection on entrepreneurial functions using price objection as an indices on the production of pure water in cross river state and uphold that objection whenever they occur are of value because they show the entrepreneur: (1) the way, the customer is reacting to the form of his presentation, (2) the way, the customer is reacting to the information contained in the presentation, (3) the areas that need special clarifications, (4) the obstacle that remain to be overcome before the customer feels able to commit himself to a final decision, (5) the way, the customer is reacting to the increasing pressure the entrepreneur is putting on him to make a decision.

\subsection{Who Is an Entrepreneur?}

According to Graham (2004) the entrepreneur brings to light a differentiator, something unique, which represent value in the eyes of the buyer or consumer. The idea is that the person at the helm should consider the organization as operating under a process designed to provide value to the consumer. In all aspect, businesses should strive towards achieving this goal that is, value to the consumer. If this is done then the organization is entrepreneurial or represents entrepreneurship.

The entrepreneur is someone who sees change as normal and healthy. Usually, the entrepreneur does not bring about change. Rather he "search for change, responds to it and exploits it as an opportunity". He must at all times treat his customers with utmost care responding to their complaints if any. Complaints, according to the business ultimate resource dictionary, are an expression of dissatisfaction with a product or service, either orally or in 
writing, from an internal or external customer. A customer may have a genuine cause for complaint, although some complaints or what is also regarded as objections may be made as a result of misunderstanding or an unreasonable expectation of a product or service. How a complaint is handled will affect the overall level of customer satisfaction and may affect the long term customers' loyalty.

\subsection{Entrepreneurial Function and Customers' Objection}

The word entrepreneurial was coined early in the $18^{\text {th }}$ century by Richard Cantillon, to express a unique function that must be performed in any business activities. A businessman usually acquires and combines certain resources such, as land, buildings, labour, materials and money, for the purpose of producing goods and services for sale to customers. The businessman cannot predict with certainty what the behavior of the customer will be. The customer may like the product or service, and buy the quality he requires to satisfy his needs.

However, if the customer does not like the product or service, the businessman cannot compel him to buy. Nevertheless, the businessman must produce in anticipation of demand. Cantillon used the word entrepreneurial to express the unique risk-bearing activities, against which the businessman cannot insure.

Despite the entrepreneur's skills and abilities, he needs to understand the customer to succeed and remain in business in the long run. The understanding of customers' objection is central and strategic to entrepreneurial success. It is also apparent that the role of marketing in the society is to dictate and discover consumer needs, interpret them and deliver want-satisfying goods and services to consumers at a profit. In other words, the function of entrepreneur is to study and interpret consumer needs and behavior, and to guide all entrepreneurial activities towards the end of consumer satisfaction. No matter how lofty his ideas, techniques and products are, he should be customer oriented and not profit oriented.

An effective and efficient modern entrepreneur, who wants to maintain solvency and long run profitability in business, must know that the key to success is customer orientation, customer focus, customer care, and customer satisfaction. This is why Graham (2004) quoted Mahatama Ghandi, saying "a customer is the most important visitor in our premises". He is not dependent on us. We are dependent on him. He is not an interruption on our work. He is the purpose of it. He is not an outsider on our business. He is a part of it. We are not doing him a favour by serving him. He is doing us a favour by giving us an opportunity to serve him.

\subsection{Price Objections}

According to Adrika, Ebue, and Nnolim (1996), price is an important element of the marketing mix and in a non-regulated condition, serves as a very efficient means of resource allocation in an economy. That is if one disagrees with the proponents of the view that in the contest to bring about a coincidence of value perception on the part of the marketer and the consumer that the latter is a clear underdog. The consumer is an underdog, the argument continues, especially because he does not have all the information needed to make his decision on the appropriateness of the price for the product he consumes.

Price objections are generally the most common and the most difficult objection questions to handle. Most sales are lost because of the inability of the entrepreneur salespersons to handle questions of price. Hence, there are generally three (3) rules for handling most price objections.

(1) Handle objection by making other consideration so overwhelmingly important in the customer judgement that the value, benefits, and satisfaction of the product or services outweigh the cost. In this case you stress value, quality, efficiency, ease of use, satisfaction, turnover, profit, economy, prestige, or whatever else appears to have the greatest appeal.

(2) Do not attempt to answer or defend a price objection until you know why it has been raised and for what reason. You may use question or why technique to find out whether it is a real excuse or a relatively unimportant question.

(3) Since price is bound to come up in almost every presentation of entrepreneur offer, anticipate and control its introduction to the greatest extent possible.

\subsection{Why Customers Object to Price}

The price objection should be seen by entrepreneur as a matter to be met with calm confidence and overcome by skilful conviction, because a customer who says "it costs too much" may mean that:

(i) He has not got the money

(ii) He has not budgeted to pay as much

(iii) He assumes it would cost less 
(iv) He has in mind the lesser price of your competitors

(v) He is trying to bargain

(vi) He is using price as an excuse for some other reasons

(vii) You have not succeeded in convincing him.

\subsection{Basic Techniques for Handling Customers' Objection}

It is apparent that producers of sachet water in Cross River State dismissed customers' objections out rightly.

Balsey and Birsner (1987) and Strafford and Grant (1986) summarized and opined the following techniques for handling customers' objections:

1) Acknowledge and convert the objection - (often referred to as Boomerang technique). This technique involves using the objection as a reason for buying. For example, a prospective customer might say "the price is too high". The reply should be "yes" the price is high because we use the finest materials. Let me show you." This technique is most effective when used by skilled salespersons, and since it is a strong technique, it should be softened by a smile and friendly look. It is especially effective in meeting objection not strongly backed by facts or reasons.

2) Outweigh - offset a valid objection by:

(a) acknowledging the validity of that objection

(b) trying to outweigh it by enumerating all the benefits that will come to the customer (buyer) if they go ahead and purchase in spite of this valid problem.

3) Postpone - the postpone technique is used when the objection will be dealt with later in the presentation: we could say, "I am going to address the point shortly. I think my answer will make better sense then".

4) Agree and neutralize - here a sales person agrees with the objection, then shows that it is unimportant. A salesperson would say "that's true and others have said the same. However, they concluded that issue was outweighed by the other benefits.

5) Accept the objection - sometimes, the objection is valid. Let the prospective customer express such views, probe for the reason behind it, and attempt to stimulate further discussion on the objections.

6) Denial - When a prospective customer's objection is clearly untrue based on misinformation, it is wise to meet the objection head on with a firm denial. This technique must be carefully used because it flatly contradicts the prospective customer's objection and tells him that he is wrong. Use it only in those rare cases when he voices incorrect objections or attacks your company or product or services with derogatory statement.

7) Ignore the objection - This technique is used when it appears that the objection is stalling mechanism or is clearly not important to the prospective customer. In practice the techniques can be employed in this way: prospect: "your last statement sounds pretty far fetched to me". The salesperson using the Passover techniques or ignore techniques may reply thus "well, Mr. Effiong, we try to point out everything of possible interest. You did seem interested in our feature. If you will note this cover again...."

8) Alternatives - you can overcome the problem by offering an alternative product or service. Remember, though, that if you are convinced that the original product or service offered was the best one for the customer, try to boomerang or outweigh (depending on the circumstances) the objection before offering alternatives.

9) Offer proof - where a customer is unsure that a product or service will do what it is supposed to do, offer proof by way of: (a) a third party referral, (b) newspaper/ magazine articles, (c) examples (d) demonstrations.

10) Isolation - Sometimes customer continue to offer objection after objection, all of them of relatively minor nature. Providing you are convinced that the product or service is right for them, and providing you have a good answer for their latest objection, ask the following questions: "that's a valid point, providing I am able to solve that one for you, would you want to go ahead and purchase this item (service)?" if they say "No" you have not really found the real objections yet, so you can go ahead and probe for it. If they finally say "Yes", answer the objection and follow a closing question. 


\section{Methodology}

The research adopted the survey research design, whereas data were sourced from both primary and secondary sources. The primary data from entrepreneurs and customers, while, the secondary data were from literatures of previous contributors on the subject matter.

A total number of forty six (46) entrepreneurs representing sixteen (16) sachet water enterprises in Calabar, CRS and two hundred and fifty (250) consumers were used as respondents for the study. A total of two hundred and ninety six (296) copies of questionnaire were therefore distributed, and all copies, properly completed, returned and used for the analysis. However, the tool used for the analysis was the Pearson Correlation coefficient denoted as:

Where: $\mathrm{X}=$ Consumers' objections

$$
r=\frac{n \sum X Y-\sum X \sum Y}{\sqrt{n \sum X^{2}-\left(\sum X\right)^{2}} \sqrt{n \sum Y^{2}-\left(\sum Y\right)^{2}}}
$$

$\mathrm{Y}=$ Entrepreneurial functions

$\mathrm{N}=$ Number of scales

The data analysis was carried out with the aid of (SPSS).

\section{Research Results and Findings}

Two sets of questionnaire were developed for this study. The first was directed to the consumers and customers of sachet water while the second was designed for the producers. The consumer/customer questionnaire sought to determine whether the respondent had ever raised objection to the price of sachet water and to know how the entrepreneur responded to the objection. The results are presented in Table 1 and 2 below.

Table 1. Customer's reaction to whether there were price objections of sachet water industry in Calabar, CRS

\begin{tabular}{lll}
\hline Option & Frequency & Percentage \\
\hline Strongly Agreed & 81 & 32.4 \\
Agree & 91 & 36.4 \\
Neutral & 22 & 8.8 \\
Disagreed & 20 & 8.0 \\
Strongly Disagreed & 36 & 14.4 \\
Total & $\mathbf{2 5 0}$ & $\mathbf{1 0 0 . 0}$ \\
\hline
\end{tabular}

Source: Field survey 2011

The result in table 1 shows that more than $68 \%$ of the respondents consider the price of sachet costly in Calabar CRS, hence have raised price objection to the producers. Only $22 \%$ of the respondents consider the price right hence has not complained. Table 2 presents the assessment of respondents on the entrepreneurs' response to the objections raised by the customers.

Table 2. Customers' reaction to whether the entrepreneurs efficiently handled the price objections by customers

\begin{tabular}{lll}
\hline Options & Frequency & Percentage \\
\hline Strongly Agreed & 8 & 3.2 \\
Agreed & 11 & 4.4 \\
Neutral & 22 & 8.8 \\
Disagreed & 85 & 34.0 \\
Strongly Disagreed & 124 & 49.6 \\
Total & 250 & 100.0 \\
\hline
\end{tabular}

Source: Field Survey 2011

The result shows that $86 \%$ of the respondents either strongly disagreed or disagreed that the entrepreneurs handled their price objection satisfactorily, against $7.6 \%$ who said that they were satisfied. This is a clear sign 
that the entrepreneurs were not taking the issue of customer objections seriously, hence did not regard it as an important entrepreneurial function.

The results of the questionnaire administered to the entrepreneurs are presented in table 3 below. The results show that the entrepreneurs acknowledged that efficient handling of objections is central and strategic to entrepreneurial success $(82.6 \%)$; that it is handled affects the long term customer loyalty $(78.3 \%)$. Price objection affects entrepreneurial profit $(86.9 \%)$ and finally that there is a relationship between customers' objection and entrepreneurial functions $(82.6 \%)$.

Table 3. Response of the entrepreneur on the strategic benefits of effective objection handling

\begin{tabular}{llll}
\hline $\begin{array}{l}\text { Question options for the producers of sachet water } \\
\text { in Calabar CRS }\end{array}$ & Yes & No & $\begin{array}{l}\text { Percentage of } \\
\text { positive } \\
\text { response }\end{array}$ \\
\hline $\begin{array}{l}\text { Customers' objection is central and strategic to } \\
\text { entrepreneurial success }\end{array}$ & 88 & 82.6 \\
$\begin{array}{l}\text { Customers' objections handling affects long term } \\
\text { customer loyalty }\end{array}$ & 36 & 10 & 78.3 \\
$\begin{array}{l}\text { Price objection affects entrepreneurial profit } \\
\begin{array}{l}\text { There is a relationship between customer's } \\
\text { objection and entrepreneurial function }\end{array}\end{array}$ & 40 & 6 & 86.9 \\
\hline
\end{tabular}

Source: Field survey, 2011

\section{Hypotheses Testing}

\section{Hypothesis 1}

$\mathrm{H}_{\mathrm{o}}$ : There is no significant relationship between consumer's objection and entrepreneurial function.

$\mathrm{H}_{1}$ : There is a significant relationship between consumer's objection and entrepreneurial function.

Table 4. Descriptive statistics of study variables

\begin{tabular}{llll}
\hline & Mean & Std. Deviation & $\mathrm{N}$ \\
\hline Entrepreneur Function & 2.88 & .619 & 16 \\
Consumers' Objection & 2.38 & .500 & 16 \\
\hline
\end{tabular}

Source: SPSS output on the analysis of research data

The result of the univariate analysis as shown above in table 4 . The mean score (x) obtained for the impact of consumers' objection on entrepreneurial function is moderately weighty $(\mathrm{x}=2.88)$. Entrepreneur of sachet water operation were of the opinion that consumers' objection is significant to business success as shown in the mean score of 2.38 though it was averagely weighty.

Table 5. Pearson correlation

\begin{tabular}{llll}
\hline & & $\begin{array}{l}\text { Consumers' } \\
\text { Objections }\end{array}$ & $\begin{array}{l}\text { Entrepreneurial } \\
\text { Function }\end{array}$ \\
\hline Consumers' Objections & Pearson Correlation & 1 & $.592^{*}$ \\
& Sig. 2-tailed & & .016 \\
& $\mathrm{~N}$ & 16 & 16 \\
Entrepreneurial Function & Pearson Correlation & $.592^{*}$ & 1 \\
& Sig. 2-tailed & .016 & \\
& $\mathrm{~N}$ & 16 & 16 \\
\hline
\end{tabular}

* Correlation is significant at the 0.05 level (2-tailed).

Source: SPSS output on the analysis of research data 
The result shows that consumer objections are positively associated with entrepreneurial function $(\mathrm{r}=.592>$ 0.05 ) as it shows a positive association. The Pearson correlation coefficient(r) indicate a gigantic relationship and since it is greater than 0.05 , the alternative hypothesis which states that there is a significant relationship between consumer's objection and entrepreneurial function is accepted.

Hypothesis 2

$\mathrm{H}_{0}$ : Entrepreneurs are not responsive to consumers' price objection in Calabar, CRS.

$\mathrm{H}_{1}$ : Entrepreneurs are responsive to consumers' price objection in Calabar, CRS.

Table 6. Pearson correlation

\begin{tabular}{llll}
\hline & & $\begin{array}{l}\text { Entrepreneurial } \\
\text { Responsiveness }\end{array}$ & Price Objections \\
\hline Entrepreneurial & Pearson Correlation & 1 & .021 \\
Responsiveness & Sig. 2-tailed & & .747 \\
& $\mathrm{~N}$ & 250 & 250 \\
Price Objections & Pearson Correlation & .021 & 1 \\
& Sig. 2-tailed & .747 & \\
& $\mathrm{~N}$ & 250 & 250 \\
\hline
\end{tabular}

Source: SPSS output on the analysis of research data

Using data from customers, the result shows that entrepreneurs of sachet water production in Calabar Cross River State are negatively responsive to price objection $(\mathrm{r}=.021<0.05)$ as it shows a negative association. The Pearson correlation coefficient(r) indicate a small relationship and since it is less than 0.05 , the null hypothesis which states that Entrepreneurs are not responsive to consumers' price objection in Calabar, CRS is accepted.

\section{Discussion, Conclusion and Recommendation}

The purpose of this study was to investigate the impact of consumers' objection on entrepreneurial function and to examine if entrepreneurs of sachet water in Calabar, Cross River State are responsive to consumer price objections. From the foregoing results it was discovered that: (1) there is a significant relationship between consumer's objection and entrepreneurial function (2) entrepreneurs of sachet water production in Calabar, Cross River State are not responsive to consumers' price objection (3) there is a relationship between consumer's objection and long term customer loyalty.

The positive correlation between consumer's objection and entrepreneurial function is likely to have been predicated on the fact established in this study that the way consumers' objections are handled will affect the overall level of consumer satisfaction and may affect the long term customer loyalty. It is important for entrepreneurs to have a clear procedure for handling consumers' objection which must be respected in all instances. The result also revealed that consumer's objection on price was hinge on the fact that, States in Nigeria without access to potable water are selling at a cheaper rate compared to what is prevalent in Calabar. This could lead to a continuous decrease in patronage by consumers who are dissatisfied with the poor response of the entrepreneurs to their objections. The observed decline in the number of entrepreneurs producing sachet water could probably be linked to this decline in patronage of the product in the State.

It is indeed important to note that price is the most convenient objection a prospect can use to thwart sales effort (Breithaupt, 2007). This requires then that objections should be adequately treated with caution and proficiency. The entrepreneur must expect and welcome all sorts of objections. They should be noted for future references and study how to answer those objections. The entrepreneur needs to understand that to succeed and remain in business in the long run, requires being customer orientation, customer focus, customer care, and customer satisfaction; as satisfied customer can be a customer for life and the entrepreneurs' best sales person. Hence, when objections are made it must be taken with utmost seriousness and alacrity.

To this end, entrepreneur should be conscious of the fact that, to have a competitive edge in a competitive environment is the ability to recognize customer objections. The effective and efficient management of such objection is the basis for entrepreneurial success in any economy; lack of precedent to customers, who are the reasons for which entrepreneur exists, usually lead to disagreement or uncertainty as to how the entrepreneur would succeed. The failure of an entrepreneur capable of harnessing the factors of production is a major weakness as well as a threat to a growing economy like Nigeria. 
The Cross River State Government should therefore, create an enabling environment for competitions to strive, by providing soft loans, and encouraging investors in the sub-sector of the economy.

If this is done it will not only help to decrease price through market forces, but also make quality water available to tourist.

\section{References}

Adrika, E. O., Ebue, B. C., \& Nnolim, D. (1996). Principles and Practice of Marketing. Enugu, Nigeria: Jamoe Enterprises.

Balsey, R. D., \& Birsner, E. P. (1987). Selling: Marketing Personified. Chicago: Dryden Press.

Breithaupt, T. (2007). Overcoming Price Objections: Secret Selling Tips. Retrieved from www.spectrain.com.

David, J., \& Geoff, L. (2006). Selling and Sales Management (Pearson Education). Prentice Hall London.

David, A. P. (2007). Overcoming Sales Objection - The Price Objection of “It's too expensive". David Peterson's Search Engine optimization guide.

Graham, Y. J. (2004). The Culture of Entrepreneurship. Treasure Books Co. Ltd, Douala, Republic of Cameroon.

Kalu, P. O., \& Anyaogu, P. M. (2001). Principles of Selling: A Practical Approach. Aba, Nigeria: Pen Paper Publishing.

Nwosu, I. E. (2001). Service Quality and Customer Expectation. In Ewurum, U. J. F. (Ed.), Managing Service Quality in the Nigerian Public Sector. Enugu, Nigeria: Smartlink Publishers.

Nwosu, I. E. (2001). Marketing Communications Management and Media Dominion. Lagos: Afri Tower Ltd.

Strafford, J., \& Grant, M. (1986). Effective Salesmanship management. London, William Heinmann Ltd. 